TURIZAM

Volume 20, Issue 3

$141-152(2016)$

ORIGINAL

SCIENTIFIC PAPER

\title{
Valorization of the Pelister National Park (Macedonia) for hiking, sport, education and recreational tourism
}

\author{
Nikola V. Dimitrov ${ }^{\mathrm{A}}$, Cane Koteski ${ }^{\mathrm{A}}$, Zlatko Jakovlev ${ }^{\mathrm{A}}$, \\ Tanja Angelkova Petkova ${ }^{A}$, Dejan Metodijeski ${ }^{A}$, Dusko Josevski ${ }^{A}$ \\ Received: September 2016 | Accepted: October 2016 \\ DOI: 10.18421/TRZ20.03-03
}

\begin{abstract}
Pelister National Park is the oldest Park inMacedonia and it's established in 1948. The Park has an abundance of natural and anthropogenic geographical features.Mountaineering, alongside with sports, education and recreational tourism are the leading attractions for the tourists in the Park, which is evident from the system of trails suitable for these activities. The Park has great potential to harmonize the needs of different users. The article is based on empirical research and a review of relevant literature. The empirical research was conducted on a sample of 124 respondentsin order to show the potential for the development of mountain, sport, educational and recreational tourism. The research includes interviews with climbers - presidents of mountaineering organizations in Bitola and the management team of Pelister. Through the research we value the elements referring to attracting visitors to sports and recreation, as well as the elements of influence and management of natural resources in the PelisterNational Park. The results showed that National Parkis mostly practiced for mountaineering and climbing. From sports activitiesthe ones that dominated are skiing, Nordic running and cycling. Also the Park is a place for education and place with potential of developing health tourism.
\end{abstract}

Key words: tourism, evaluation, mountaineering, sport, education, recreation, Pelister National Park

\section{Introduction}

Many authors have confirmed that the natural and geographical features of mountains are destined for hiking, sports, education and recreation. Thus, mountaineering, sport, education and recreational tourism have become very attractive forms of tourism that appeal to millions of tourists. Notable authors who explore sports and recreational tourism are (Standevan, De Knop, 1999; Plavša, 2007; Papadimitrou, Gibson, 2008; Weed, 2008). As for the experiences of

A Faculty of tourism and business logistics - Gevgelija, University Goce Delcev - Stip, Krste Misirkov, 2000, Stip, R. Macedonia

Corresponding author: nikola.dimitrov@ugd.edu.mk 
cycling for sports and recreational tourism in the National Park Fruska Gora and Triglav, theyare explored by (Vujko, Tomka, 2009; Vujko, Plavša, 2010; Vujko, Plavša, 2014; Polajnar, Drofenik, 2015).

The Pelister National Park is situated in the southwestern part of Macedonia and is part of the Baba Mountain. The total area of the Baba Mountain with its peak Pelister, also calledthe mountain range of Pelister is $402.9 \mathrm{~km}^{2}$, of which $171.5 \mathrm{~km}^{2}$ (17.150 ha)belong to the Park, which represents $43.42 \%$ of the mountain area.

The total length of the Pelister National Park in north - south length is $22 \mathrm{~km}$ and east - west width of $14 \mathrm{~km}$. The Park begins from 891 to 2601 meters above sea level and has an average altitude of 1746 meters. Accordingly, the Park belongs to the group of high mountain national parks, with about 50 peaks over 2000 meters, and is also the southernmost mountain with alpine species.

Pelister National Park was established in 1948 due to endemic five-spike pine Molika (Pinus peuce, discovered by Austrian botanist August Grisebach in 1839), diverse geological structure, geomorphology (stone rivers, glacial lakes, and cirques etc.), climate and hydrographic peculiarities and endemic flora and fauna.

The first observed mountain climbing on Pelister was made by Ami Bue in 1836, followed by climbs of August Grisebach in 1839, Edmund Spenser in 1850, Henrih Bart in 1862 and other travel writers and scientists (Matkovski, 1992; Popovska, 1999).

The Baba mountain with its peak Pelister owns anthropogenic values, represented by archaeological sites (ancient citadel, a tower, a relic of the old Roman road Via Egnatia, medieval buildings, churches, monasteries, etc.), memorials of the Ilinden Uprising (1903), for World war I (1914-1918) and World war II (1941-1945).

The first organized activity in the mountain beganin 1925 when the children's camp (1270 masl) "Shtamparevac" was built on Pelister as a sanatorium, which was the first building for collective housing - the forerunner of further organized tourism activity. Earlier, in 1918 on the same location and in the monastery Holy Mary, Mother of God in the village of Trnovo, a group of French doctors built a small sanatorium rehabilitation for wounded and sick soldiers. In 1926in Bitola the mountaineering company "Pelagonija" was established, a few years later renamed to PD "Pelister" (Stamenkov, 1987, 10/11).

In 1930 in Bitola another mountaineering association "South Lakes" was formed. Under an initiative of climbers form Bitola, two mountain lodges were built in 1938 - one in the area calledBegova Cesma (1420 m) and another one in the area of Kopanki (1610 m).

After World War II, in 1945 PD "Pelister" was restored in Bitola with over 2000 members. In addition to hiking and forestry this organizationalso dealt with tourism.

Another lodge in Golemo Ezero (Big Lake) was built in the Park, a lodge in the locality Golema Livada (Great Meadow), then a hunting lodge on the site Siroka (Extensive), several villas in the locality Begova Cesma (Bey Fountain), while Mountain Lodge Kopanki was renovated several times as well as the TV relay for Pelister.

Today the tourism infrastructure in the area of the PelisterNational Park includes: three major roads, cable car, two ski lifts, more roads for forestry needs, TV relay, two lodges, a weekend resort, a hotel, several cottages, hunting and forest house, information center, two monasteries, six churches, more regulated and impounded fountains, marked trails (hiking, climbing, cycling, horse riding and education - children and historical path), and a dozen of picnic areas (equipped with benches, fountains, tables, waste baskets, viewpoint etc.).

Pelister National Park on a national level and beyond is primarily known as a tourist destination for its unique natural geographical features suitable for hiking, sports and educa- 
tion which contribute to healthy holiday and a great recreation through different programs for active holidays.

The area of the PelisterNational Park has excellent opportunities - potential for the development of mountain, sports, educational and recreational tourism. For that reason it was necessary to approach the tourist valuation and evaluation, i.e. to determine its useful tourist value as a tourist destination for the development of mountaineering, sport, education and recreation (Reynard, Fontana 2007; Pereira, et al., 2007; Comanescu, et al., 2009; Marinoski, 2010; Dimitrov, Koteski, 2015).

In this context, in the last ten years in the Park wereimplemented the following activities: marking of multiple paths for recreation and hiking, bike trails, covered ski trails, an info center was build,educational classroom in nature, educational historical path and organization of different marches and mountain marchesthroughout the year and similar.

After all, in the past several years the condition of the PelisterNational Park has been significantly deteriorated as a result of the non-functioning of the oldest mountain lodge Kopanki (burnt down in 28.01.2013) and from this year the closure of the children resort "Pelister", as well as the neglected markation and the destruction of several attractive sites. All this results in a significant decrease in the number of climbers and recreation tourists and the overall activities of hiking, sports, education and recreation.

The aim of the research is to focus on - register the current state and define the priorities for overcoming the most important specific issues for hiking, sports, recreation and education for visitors to the Park.

The aim of the survey is to confirm and show the potential of the Pelister National Park for hiking, sports, educational and recreational tourism represented by valuing the natural and cultural sites. The research uses quantitative and qualitative methods to determine the value and the tourist attraction for hiking, sports, education and recreational tourism(Du Cros, 2001; Hadžić, et al., 2010).

\section{Methodology}

In the process of scientific research, suitable methods, quantitative - statistical and qualitative - survey and interview are used, which allow great freedom in the research andevaluations of results.

The quantitative method relies on statistical processing of answers to two questions in the poll with hikers (Table 1,2). While the qualitative method starts from the survey and interviews.

Empirical research was done through a questionnaire and it was completed on a sample of 124 respondents - active mountaineers (94 male, 30 female, age at 10 to 60 and up) and interviews with competent persons (presidents of mountaineering associations in Bitola about the opinion of the management team of Pelister National Park).

In the research an important position takes opinions of the authors as experts in the field tourism.

The starting point of the research is the group of three variables (changeable value, variously, shiftily), to identify the views of the respondents in relation to the geographical, natural and anthropogenic trends in the Pelister National Park's development of mountaineering, sport, education and recreational tourism. 
The first group of variables givesan opinion on the appropriateness of the mountainous areas or locations for mountain lodges, the development of sports and recreational tourism. The second set of variables is interviewing people in connection with the names of those areas. A third variable is determining the suitability of sites for mountaineering (recreational walking, difficult hiking - hiking, climbing), sports (skiing, Nordic running, cycling, running, etc.), education and recreation.

The qualitative method isconsidered more reliable and therefore is accepted as a valid method of valuation - assessment of natural and cultural values relevant for hiking, sports, education and recreational tourism. Itis estimated every element who is rated by the two entities or departments. The upper assessment, presented in the tables 4, 5, 6, is consisting of an average grade received from the competent persons (presidents of mountaineering associations and heads inthe Pelister National Park). While the lower part of the valuation revaluation - evaluation wasobtained by the authors of the paper.

For the valuation of buildings and sites for hiking, sports, education and recreation in the Pelister National Park a qualitative method is used. Thus, the valuation of the Park will be done according to the seven parameters with their numerical value from 1 to 5 (See: Table 3).

Through the data obtained by the preliminary hypothesis is that the PelisterNational Park is an adequate space for the development of mountaineering, sport, education, recreation and tourism. The need to design a studious survey of tourist valuation of the area, and spatial plan of the Park is confirmed. The research and the spatial plan will allow for the development of natural and cultural resources in the Park to turn them into far-reaching and beneficial areas for regional business and economics, ecology and sustainable development (Standevan, Knop, 1999; Cutumisu, Cottrell, 2004; Serrano, Gonzales-Treueba, 2005; Pralong, 2005; Pereira, et al., 2007; Reynard, Fontana, 2007; Erhartič, 2010; Vujko, 2012).

\section{Results}

Mountaineering, sport, education and recreational tourism in the PelisterNational Park can be developed in various forms and in accordance with the basic features of the terrain, climate specifics, hydrographic network and biodiversity.

Thus, according to the configuration of the terrain, slope, forestation etc. mountaineering is practiced in the following types: low forest, high forest and alpinism. In the lower parts of the mountain up to 1800 meters, recreational walking or easy hiking is practiced while in the high parts of 2000 meters, high or difficult hiking dominates in addition to rock climbing, mountain climbing, and hiking in rocky areas. The sport activities include: running, skiing, cycling, Nordic running etc. For the purpose ofmountaineering, sport, education and recreation there are more than 40 marked mountain hiking, sports and educational trails in the length of $100 \mathrm{~km}$.

Places where sport activities can be practiced are mountain huts, resorts and picnic areas. The most favorable periods for sport and recreation are from March to October. The Park organizes winter games in Nordic skiing and running ("Pelister's giant slalom") and in May a memorial mountainmarch ("Dimitar Ilievski") as well as in October, a mountain biking cross and more.

Places for ducation or "Classroom in nature" under the principles of the "Forest pedagogy" includethese several paths and trails in their form of teaching: Children's educational trail, then the site "Seven wells" or the area of the Information Centre and educational path to Gole- 
ma Livada, historical and educational - hiking trail, the sites Golema Livada, Mala Livada, Begova Cesma, Larotjčin Kamen, Jorgov Kamen, Palisnopje and others.

Hiking, sport and recreation are necessary to prevent efficiently the typical diseases of modern civilization such as: visible nervousness due to different tensions, urban noise, air pollution (Simonsen, et al., 1998; Pereira, et al., 2007; Comanescu, et al., 2009).

Considering all of the above mentioned and according to the medical practice, we can add that the PelisterNationalParkis also a good "air - sun bath with the best remedies: sun, water, air," where all of them are available to every visitor. Pelister is true for the Latin proverb: Quantum satis (Take the amount needed - air, water and sun). Here, without any exaggeration, there is potential for development of health tourism. The mountain is suitable for post-operative rehabilitation, as well as for diabetitians (most appropriate altitude is 800-100o meters), for the releasing of nervous tension, for respiratory and cardiac patients (1000-1200 meters), for asthmatics (1200-1400 m.) for anemia (1400-1600 m.) and similar.

In our research, the most important question for the respondents in the first group of variables refers to the benefits of hiking, sports, education and recreation. So, in the first question of the survey the respondents are asked to nominate areas that they think are most suitable destinations for hiking, sports, education and recreational tourism.

\section{Question 1. Do you think the Pelister National Park is suitable for the development of mountaineering, sports, education, tourism and recreation?}

On this question all 124 respondents (100\%), answered YES as shown on Table 1 and Figure 1 toconsider the Pelister National Parkarea is suitable for development of mountaineering, sport, education and recreational tourism.

Table1. Respondents by residence

\begin{tabular}{|c|c|c|c|c|c|c|}
\hline \multicolumn{2}{|c|}{} & \multicolumn{5}{c|}{ The residence of respondents } \\
\cline { 3 - 7 } \multicolumn{2}{|c|}{} & Bitola & Prilep & Skopje & Other places & \multicolumn{2}{c|}{ Total } \\
\hline \multirow{3}{*}{ Gender } & Male \% & 71 & 13 & 7 & 3 & 94 \\
& & 72,45 & 86,67 & 87,5 & 100 & 75,81 \\
\cline { 2 - 7 } & & 27 & 2 & 1 & 0 & 30 \\
\hline \multirow{3}{*}{ Total: } & 124 & 27,55 & 13,33 & 12,50 & 0 & 24,19 \\
& $100 \%$ & 79 & 15 & 8 & 3 & 124 \\
\hline
\end{tabular}

Source: Calculations based on the questionnaire and interviews

Regarding the gender structure $75.8 \%$ of the respondents were men and $24.2 \%$ were women. Ofthe total number of respondents (124), most of them, 98 are from Bitola (79.03\%), 15 from Prilep (12.10\%), 8 from Skopje (6.45\%), and 3 (2.42 \%) from other places (one from Resen, Ohrid and Kavadarci).

According to the age structure of the respondents most of them were aged 40-59 (31.4\%), followed by the age of 20-39 years (approximately 30.7\%) then 10-19 years (26.6\%), and the small number of those were at the age 60 and older (about 11.3\%) (See Table 2). 


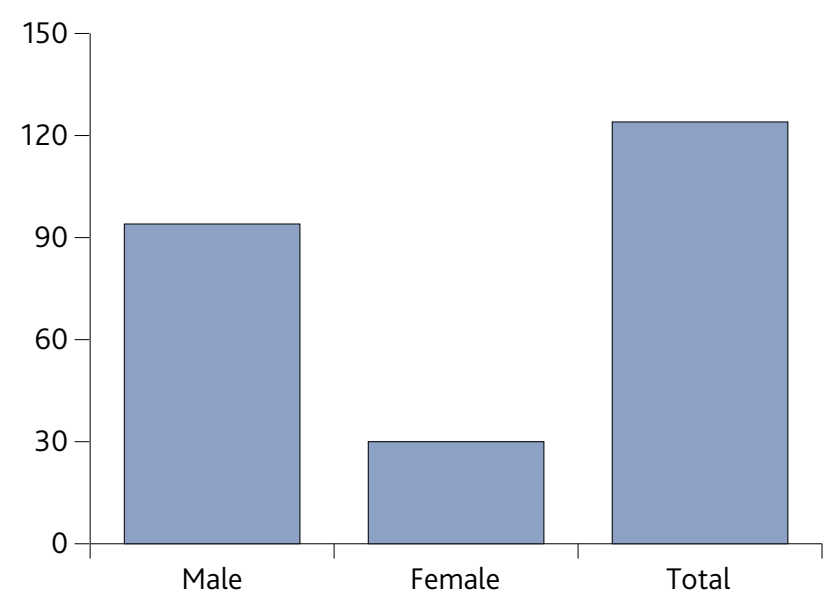

\begin{tabular}{|c|c|c|c|c|c|c|}
\hline No & 0 & 0 & 0 & 0 & 0 & 0 \\
\hline \multirow[t]{4}{*}{ Yes } & 94 & 75,8 & 30 & 24,2 & 124 & 100 \\
\hline & Count & $\%$ & Count & $\%$ & Count & $\%$ \\
\hline & \multicolumn{2}{|c|}{ Male } & \multicolumn{2}{|c|}{ Female } & & \\
\hline & \multicolumn{4}{|c|}{ Gender } & \multicolumn{2}{|c|}{ Total } \\
\hline
\end{tabular}

Figure 1. Number of persons by gender and percentage of participants in the study to evaluate the possibilities of Pelister for the development ofmountaineering, sports, educationand recreational tourism Source: Calculations based on the questionnaire and interviews

Table2. Age groups of respondents

\begin{tabular}{|l|c|c|c|c|c|}
\hline \multicolumn{7}{|c|}{ Age groups of respondents expressed in years } \\
\hline & $10-19$ & $20-39$ & $40-59$ & 60 and more & Total \\
\hline Number of persons & 33 & 38 & 39 & 14 & 124 \\
\hline Percent (\%) & 26,61 & 30,65 & 31,45 & 11,29 & 100 \\
\hline
\end{tabular}

Source: Calculations based on the questionnaire and interviews

\section{Question 2. What are your reasons for visitingthe Pelister National Park?}

Most of them reported that the Park is visited for the purpose of hiking (40.3\%), and recreation (37.9\%), sports (12.1\%), education (about 7.3\%) and other (2.4\%).

In addition to the informationsabove, are the information provided by the officials from the PelisterNational Park that the Park is visited by over 30.000 visitors annually. Generally, these are visitors from Macedonia and especially from Bitola and the surrounding places, while about $15 \%$ are foreign visitors.

Most foreign tourists visit Pelister during the summer season. These are mostly tourists from the Netherlands, Israel, Germany, Italy, Poland, Czech Republic, Finland, Greece, Albania, etc. Few visitors come from Australia, America and Canada (a good deal of them are our emigrants who visit the homeland), as well as visitors from Albania, Greece, Bulgaria, Serbia, Slovenia and Croatia. 


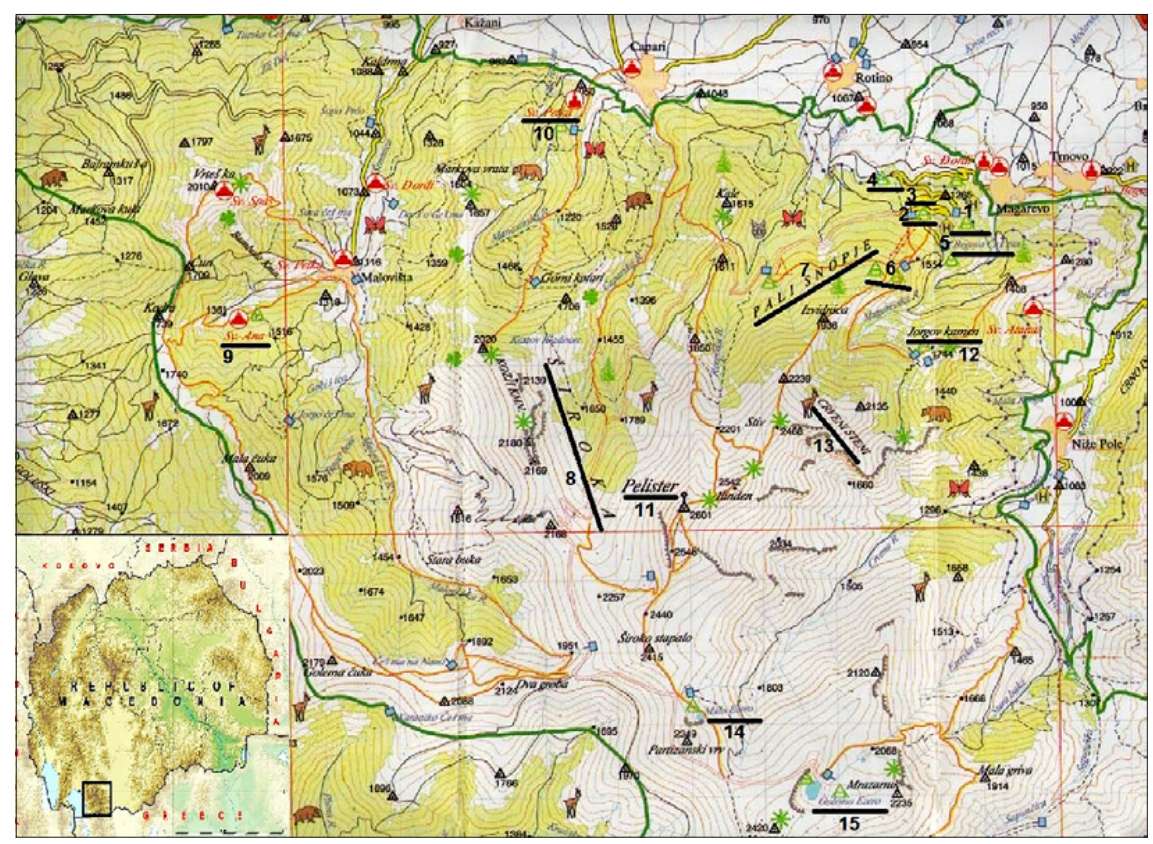

Figure2. Important locations and areas (1-15) for hiking, sports, education and recreation in the area of National Park Pelister

Source: Markoski, Dimitrov, 2013

\section{Discussion}

It is certain that the arrangement of sites, buildings with marked trails, signs, informative and educational boards, lighting, fountains, benches, waste baskets, sports trim trails with equipment for recreation and other infrastructure would greatly contribute to the popularization of the Park and lead to more visitors (Stamenković, Plavša, 2009).

In the previous description we showed data for several trails for hiking, mountaineering, sport, education and recreation, but in the area of the Pelister National Park there are also more anthropogenic facilities that can offer and attract even more tourists. Nevertheless, for the purpose of sport, education and recreation,there are accommodation facilities for guests - tourists, such as hotel "Molika" and children resort "Pelister". Several villas in the locality "Beogova Cesma", mountain lodge "Kopanki" andmountain lodge "Big Lake "also can be included. Other facilities that are able to accommodate guests are located at the foot of the mountain and beyond the boundary of the Park. Those are: tourist resort ZLTC "Pelister" near the village Niže Pole, hotel "Sumski Feneri", hotel "Sator", hotel "Ris" as well asfacilities in the settlements Magarevo Pelister, Turnovo, Dihovo and Nizo Pole where there are holiday houses and farmhouses.In this context we should mention two monasteries within the Park, St. Anna near Malovishta and St. Petka near Capari. In both monasteries there are lodgings for guests. Also, beyond the boundary of the Park, in the village of Trnovo, Monastery St. Marywhich has several guest rooms in its quarters. Please note that all the above guest accommodations are not subject of our research, they will be mentioned on another occasion. 
Table 3. Display of seven parameters with their values

\begin{tabular}{|l|l|l|l|l|l|}
\hline \multirow{2}{*}{ PARAMETER } & \multicolumn{5}{|c|}{ NUMBER VALUE } \\
\cline { 2 - 6 } & $\mathbf{1}$ & $\mathbf{2}$ & $\mathbf{3}$ & $\mathbf{4}$ & $\mathbf{5}$ \\
\hline Accessibility & Small trail & Marked trail & Ruined dirt road & Forest road & Asphalt road \\
\hline Infrastructure & No & Just fountain & Incomplete & Pass & Full \\
\hline Signalization & No & Only mountain & $\begin{array}{l}\text { Mountain with } \\
\text { boards }\end{array}$ & $\begin{array}{l}\text { Device, regularly } \\
\text { maintained }\end{array}$ & Polifunkci-tional \\
\hline Environment & $\begin{array}{l}\text { No Contaminated } \\
\text { Environment }\end{array}$ & No Protection & $\begin{array}{l}\text { Only waste } \\
\text { baskets }\end{array}$ & $\begin{array}{l}\text { Seasonal } \\
\text { maintenance }\end{array}$ & $\begin{array}{l}\text { Regular } \\
\text { maintenance }\end{array}$ \\
\hline Specificity & Unknown & Not affirmed & Common & Rarity & Unique \\
\hline Importance & Unspecified & Not affirmed & Local & National & International \\
\hline Artistic value & Insufficient & Not affirmed & Local & National & International \\
\hline
\end{tabular}

Source: Compiled by the authors

In accord with all of the previously mentioned about the resources of the Park, which are important for tourism, we further evaluate the sites in the PelisterNational Park that are important for the development of mountaineering, sport, education and recreation.

The main elements of tourist valorization - valuation are seven parameters (withtheir numerical value from 1 to 5): accessibility - availability of resources (paths, roads), infrastructure (tourist services, equipment, facilities, tourist offer etc.), signalization (tourist information - boards), environment (natural and built), specific resources, the importance of resources (depending on their impact on the market and good knowledge), and the artistic value of resources (See Table 3).

Table 4. Evaluation of sites and areas for hiking, sports, education and recreation in the area of NP Pelister

\begin{tabular}{|c|c|c|c|c|c|c|c|c|c|}
\hline s.n. & Locality & 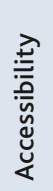 & 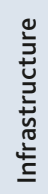 & 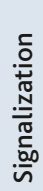 & 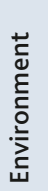 & 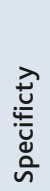 & 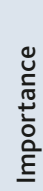 & 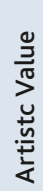 & 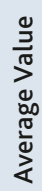 \\
\hline 1. & Children's hostel & 5 & 4 & 4 & 4 & 4 & 4 & 4 & 4 \\
\hline 2. & Information Center & 5 & 5 & 5 & 5 & 4 & 5 & 4 & 5 \\
\hline 3. & Mala Livada & 5 & 2 & 4 & 4 & 4 & 4 & 4 & 4 \\
\hline 4. & Golema Livada & 4 & 3 & 4 & 4 & 4 & 4 & 4 & 4 \\
\hline 5. & Begova Cesma - Lastojcin Kamen & 4 & 4 & 5 & 4 & 5 & 5 & 4 & 4 \\
\hline 6. & Kopnaki & 2 & 4 & 4 & 4 & 4 & 4 & 4 & 4 \\
\hline 7. & Palisnopje & 3 & 2 & 2 & 4 & 4 & 4 & 4 & 3 \\
\hline 8. & Siroka & 3 & 1 & 2 & 3 & 4 & 4 & 4 & 3 \\
\hline 9. & Monastery of St. Anna & 2 & 2 & 3 & 3 & 4 & 4 & 4 & 3 \\
\hline 10. & Monastery of St. Petka & 3 & 2 & 2 & 3 & 4 & 4 & 4 & 3 \\
\hline 11. & Peak Pelister & 3 & 2 & 3 & 3 & 4 & 5 & 4 & 3 \\
\hline 12. & Jorgov Kamen & 2 & 1 & 2 & 3 & 4 & 4 & 4 & 3 \\
\hline 13. & Red Rocks & 2 & 1 & 2 & 3 & 4 & 4 & 4 & 3 \\
\hline 14. & Small Lake & 2 & 1 & 2 & 3 & 4 & 4 & 4 & 3 \\
\hline 15. & Big Lake & 3 & 2 & 3 & 3 & 4 & 4 & 4 & 3 \\
\hline
\end{tabular}

Source: Calculations based on the questionnaire and interviews 
Valuations of 15 sites and areas suitable for hiking, sports, education and recreation, are presented in Table 4 and Figure 2.

The table notes that the only site with an average value of 5 is the Information Centre, which is equipped with a larger number of elements (showroom, hall for lectures, presentations, workshops, meetings, souvenir shop, etc., and the yard has room for rest - tables, benches, information boards etc.), which justifies its use.

Five localities and areas have an average value of 4 , which means that these places lack some things and those may be added. Most localities, i.e.nine sites and areas have an average value of 3 , which means that these are places that need more work and lots of investment in order to justify their role in hiking, sports, education and relaxation.

The widely known qualities of the Park's natural resources for several years are less visited by tourists mainly because of the lack of opportunity to be viewed by many visitors and tourists. The general condition of the accommodation capacities in the individual locations in the Pelister National Park are deteriorated (excluding hotel "Molika") which is satisfactory, whilethe mountain lodges are underequipped. Thus, the mountain lodge Kopanki has been out of service for several years because of nearly burning out to the ground and has not yet been renovated. Also the second home of Big Lake works, but with many shortcomings and out of the standards for an orderly mountain hut (water, WC, showers, electricity, internet, equipment for sport, recreation, etc.).

In a similar situation is the only children's resort "Pelister" which this year is in not in operation and its advertised for sale. To this we add the fact that the entry visit and movement within the Park is limited (from 8 to $17 \mathrm{pm}$ ) and charged (30-50 denari).

This suggests that the need to meet the wishes of the Park visitors for hiking, sports, education, recreation is of reduced dynamics. Then follows the creation of the Pelister National Park as a mountain destination as well-known brand,but first we need to start with the development of mountaineering, sport, education and recreation. This fact has already been put into question, because dramatically reduces the level of attraction to the Park, and the biggest loser are the mountain, sports, educational and recreational tourism.

As it'sseen from Table 6, the current state of hiking, sports, educational and recreational tourism is reduced to a low level. This is confirmed by the factor that there are almost no signs of modern mountain houses, conveniently arranged terrain and trails for hiking and sport and recreation. Also, every sport and recreational events are minimized. The education through the arrangement of several educational paths, outdoor classroom, info - center etc. meets the basic requirements for educational tourism.

In Tables 5 and 6 we use anevaluation of more elements that are assessed by two entities or departments. The upper assessment, presented in the tables, consists of an average grade received from the competent persons (president of mountaineering associations and heads of National ParkPelister). The lower evaluation is obtained by the authors of this paper.

The evaluation shows that the Pelister National Park is recognized as a known area for sport and recreation, with high marks, but the current situation shows that services for modern sports and recreational activities and for people with special needs are low.

InTable 6.the elements of the impact of natural resources in the social development of the local community are evaluated and related to natural resource management, regular monitoring and possibilities for negative impact on visitors.

The evaluation shows that the Pelister National Park should be constantly upgrading the management of natural resources, their regular monitoring, and monitoring of activities that will diminish any negative effect on resources in the Park caused by the visitors. 
Table 5. Evaluation of elements pertaining to attracting visitors for sport and recreation in Pelister National Park

\begin{tabular}{|l|c|c|}
\hline Elements & NP Pelister & Total \\
\hline \multirow{2}{*}{ Level of knowledge } & 3 & 3 \\
\hline \multirow{2}{*}{ Applicable component } & 5 & 5 \\
\hline \multirow{2}{*}{ Attractiveness of natural resources for special needs } & 5 & 4 \\
\hline \multirow{2}{*}{ Existence of complementary natural and cultural resources } & 5 & 5 \\
\hline \multirow{2}{*}{ Access to the natural area } & 5 & 5 \\
\hline \multirow{2}{*}{ Range of natural resources } & 4 & 5 \\
\hline \multirow{2}{*}{ Benefits of service } & 5 & 5 \\
\hline
\end{tabular}

Source: Calculations based on the questionnaire and interviews

Table 6. Evaluation of the elements of the impact and management of the natural resources

\begin{tabular}{|l|c|c|}
\hline \multicolumn{1}{|c|}{ Elements } & Pelister NP & Total \\
\hline Level of knowledge & 5 & 5 \\
\hline The impact of the natural resources on the social development & 5 & 5 \\
of the local community & 5 & 5 \\
\hline \multirow{2}{*}{ Educational and scientific importance } & 4 & 5 \\
\hline \multirow{2}{*}{ Scarce natural rarities } & 5 & 5 \\
\hline \multirow{2}{*}{ Representation of destination } & 4 & 5 \\
\hline \multirow{2}{*}{ Sensitivity of natural resources } & 5 & 5 \\
\hline \multirow{2}{*}{ Natural resource management and regular monitoring } & 5 & 4 \\
\hline Possibility of negative impact from a large number of visitors & 4 & \multirow{2}{*}{5} \\
\hline
\end{tabular}

Source: Calculations based on the questionnaire and interviews

\section{Conclusion}

Research findings show identification of more unresolved issues, and the main reasons for this are the limiting potential of insufficient number of expert staff from several areas, lack of proper strategy and spatial plan for the development of the PelisterNational Park.

The general conclusion of the research is that there is a remarkable drop in mountaineering and conditions for sports, recreation and education. Accordingly, the first priority should be arapid revitalization of the mountain houses and the children's resort. 
Second priority is making a spatial plan of the National Park. This criterion should create the conditions for solving the problems in the Park.

In this regard, we point out the most important theoretical implications for the Park, which result in the practical application of the following:

- standardization of quality services and monitoring of activities,

- addressing the negative and destructive impacts on nature and facilities,

- construction of adequate tourist infrastructure according to the chosentype of tourism,

- building new mountain houses and lodges,

- categorization of the accommodation,

- modernization of signalization and orientation in the park,

- promotion of health tourism resources,

- organizing events for hiking, sport, education and recreation,

- application of standards for mountaineering, sport, education and recreational tourism,

- management of the principle of sustainable development and preservation of the mountain, and others.

Taking into consideration the proximity of the Park to Ohrid and Prespa Lake as one of the most important tourists areas in the country, as well as the proximity to Greece and the increasing number of tourists coming from there in the past period, it'sclear that these datashould be usedfor the development of mountaineering, sport, education and recreational tourism.

\section{Acknowledgements}

On the occasion of 180 years of Ami Bue's climbing on Pelister (1836-2016) and 90 years of the first Mountaineering Association in Bitola (1926-2016).

\section{References}

Bornholm Serrano, E., González-Trueba, J.J. 2005. Assessment of geomorphosites in natural protected areas:the Picos de Europa National Park (Spain). Géomorphologie: relief, processus, environnement 3, 197-208.

Božić. S., Tomić, N. 2015. Canyons and gorges as potential geotourism destinations in Serbia: comparative analysis from two perspectives - general geotourists and pure geotourists. Open Geosciences 7-1, 531-546.

Comanescu, L., Nedelea, A., Dobre, R. 2009. Inventoring and evaluation ofgeomorphosites in the Bucegi Mountains. Forum geografic 8, 38-43.

Dimitrov, V.N., Koteski, C. 2015. Tourism geography, Stip (In Macedonian).

$\mathrm{Du}$ Cros, H. 2001. A new model to assist in planning for sustainable cultural heritage tourism. International journal of tourism research 3, 165-170.

Erharti, B. 2010. Geomorphosite assesstment. Acta geographica Slovenica 50-2,295-319.

Group of authors. 2008. Nacionalen Park Pelister, monograph 50 years, Bitola (In Macedonian).

Hadžić, O., Marković, B.S., Vasiljević, Nedeljković, M. 2010. A dynamical model for assessingtourism market atractiveness of a geos. Geotrends 2010, Novi Sad.

Hayward, P. 2002. Leisure and Tourism. Oxford 
Hudson, S. 2003. Sport and adventure tourism. Binghamton.

Management plan for National Parks Pelsiter, over 2006-2015. (In Macedonian).

Marinoski, N. 2010. Tourism geography, Ohrid (In Macedonian).

Markoski, B., Dimitrov, V., N. 2013. National Park Pelister and Baba Mountain, Hiking - Tourist Map, Geomap, Skopje; Maps: Walking and hiking trails of National Park „Pelister“.

Matkovski, A. 1992. Macedonia in the works of foreign writers 1827-1849, Skopje (In Macedonian).

Matkovski, A. 1992. Macedonia in the works of foreign writers 1850-1864, Skopje (In Macedonian).

Papadimitrou, D., Gibson, H. 2008. Benefits sought and realized by active mountainsport tourists in Epirus, Greece: Pre-and post-trip analysis. Journal of Sport and tourism 13, 37-60.

Pereira, P., Pereira, D., Caetano Alves, M.I. 2007. Geomorphosite assessment in Montesinho natural park (Portugal). Geographica Helvetica 62-3, 159-168.

Plavša, J. 2007. Sport and recreation tourism. University of Novi Sad,Department of geography, tourism and hotel management. Novi Sad (In Serbian).

Polajnar, H. K., Drofenik, U. 2015.Opportunities for developing mountain biking in the Municipality of Bohinj. Acta geographica Slovenica 55-2, 317-335.

Popovska, S., S. 1999. Ami Bue for Macedonia, Skopje (In Macedonian).

Pralong, J.P. 2005. A method for assessing tourist potential and use ofgeomorphological sites. Géomorphologie: relief, processus, environnement 11-3, 189-196.

Reynard, E., Fontana, G., Kozlik, L., Scapozza, C. 2007. A method for assessing »scientific« and »additional alues« of geomorphosites. Geographica Helvetica 62-3, 148-158.

Simonsen, S.P., Jorgensen, B., Robbins, D. 1998. Cycling tourism. Bornholm.

Stamenkov, V. 1987. Guide of mountaineering organizations in Macedonia, Mountaineering Union of Macedonia, Skopje (In Macedonian).

Stamenković, I., Plavša, J. 2009. The new age of faith tourism and Fruška Gora Mountain (Serbia). Turizam 13-2, 102-112.

Standeven, J., Knop, P. 1999. Sport and recreational tourism. Champaign.

Stankovic, M., S. 2003. Tourism - protection and valorisation, Beograd(In Serbian).

Stankovic, M., S. 2008. Tourism geographya, Beograd (In Serbian).

Tomić, N. 2011. The Potential of Lazar Canyon (Serbia) as a Geotourism Destination: Inventory and Evaluation. Geographica Pannonica 15-3, 103-112.

Tomić, N., Božić, S. 2014. A modified Geosite Assessment Model (M-GAM) and it's Application on the Lazar Canyon area (Serbia). International Journal of Environmental Research 8-4, 1041-1052.

Vujko, A. 2012. Positive aspects of the development of cycling tourism in tourist destinations a case study of Fruska Gora. TIMSActa 6, 19-28.

Vujko, A., Plavša, J. 2010. Networking of Fruška Gora lakes tourist offer throughsystem of cyclepaths - case study Sot, Bruje and Moharač. Turizam 15-1, 1-10.

Vujko, A., Plavša, J. 2014. Evaluation of Fruška Gora National Park (Serbia) for sport andrecreational tourism. Acta geographica Slovenica 54-2, 321-334.

Vujko, A., Tomka, D. 2009. How to overcome difficulties in the creating of adequate supply for cyclingtourism in the Mountains of Vojvodina-SWOT analysis-Romania proceedings - The second International Tourism conference: "Sustainable Mountain Tourism- Regional Answer to Global Challenge”, Eselnita, Romania, 316-323.

Weed, M. 2008. Sport and recreational tourism experience. Journal of sport and tourism 13-1, 1-4. 